\title{
Arsitektur Regionalisme: Jelajah Nusantara Melalui Desain Bandar Udara
}

\author{
Falahy Mohamad dan Purwanita Setijanti \\ Departemen Arsitektur, Fakultas Arsitektur, Desain dan Perencanaan, Institut Teknologi Sepuluh Nopember (ITS) \\ e-mail: psetijanti@arch.its.ac.id
}

\begin{abstract}
Abstrak - Bandara pada saat ini menjadi pusat perhatian di negara belahan dunia. Bandara merupakan gerbang daerah yang juga sebagai bangunan publik dengan resiko tinggi tentunya wajib memenuhi persyaratan teknis yang berkaitan dengan keamanan dan keselamatan. Perlu adanya pertimbangan prinsipprinsip utama mengenai terminal moda transportasi ini. Terkadang banyak sekali salah dalam menentukan atau memutuskan segala sesuatu dalam merancang. Seperti konsep desain bangunan, bahan bangunan, pola-pola ruang, dsb. Mereka hidup dalam kotak-kotak dari beton dengan atas nama modern, efisiensi dan lain-lain yang akhirnya mencoba mendefinisikan kembali arti makna ide ruang, bentuk dan sebagainya dalam paham arsitektur regionalisme melalui semiotika pengenalan tanda-tanda dan ekplorasi metafora lokalitas yang ada di Pekalongan. Permasalahan minimnya lokalitas sudah banyak ditemui dibeberapa daerah di Indonesia. Seringkali aspek desain dari bandara lebih kearah internalisasi dengan mengusung teknologi muktahir namun kesan yang timbul hanya unsur modern saja, tetapi nilai kelokalan justru tidak diperhatikan. Dalam perencanangannya, bagaimana caranya identitas-identitas yang melekat pada Pekalongan bisa dimasukkan kedalam arsitektur.
\end{abstract}

Kata Kunci-Bandara, Lokalitas, Metafora, Pekalongan, Regionalisme, Semiotika

\section{PENDAHULUAN}

M ANUSIA semakin kedepan semakin serba cepat untuk memenuhi aktivitas-aktivitas yang dijalaninya. Pada aktivitasnya manusia tidak lagi dibatasi oleh ruang-ruang yang mengaturnya karena sudah mempunyai perubahan dalam sebuah makna ruang itu sendiri. Sehingga batas-batas fungsi ruang kurang jelas dan memudar karena terdapat banyak aktivitas yang bertabrakan atau saling tumpuk dalam satu ruang.

Perubahan karena adanya globalisasi juga terjadi didalam gaya hidup yang dimiliki oleh masyarakat. Pengaruh globalisasi membuat gaya hidup masyarakat di dunia menjadi gaya hidup yang serba cepat. Gaya hidup yang menuntut adanya serba cepat ini tercemin di dalam pola perilaku masyarakat dalam menjalankan kehidupan sehari-hari.

Hal ini kemudian direspon dengan cepat di erapemerintahan Jokowi. Aktivitas masyarakat Indonesia mengalami perubahan yang signifikan. Perubahan tersebut merupakan hasil dari fokus pembangunan di awal pemerintahan era-Jokowi yaitu pembangunan infrastrukstur. Adapun pembangunan infrastruktur yang paling berperan kebijakan pembangunan tol darat, pembentukan tol laut dan tol udara.

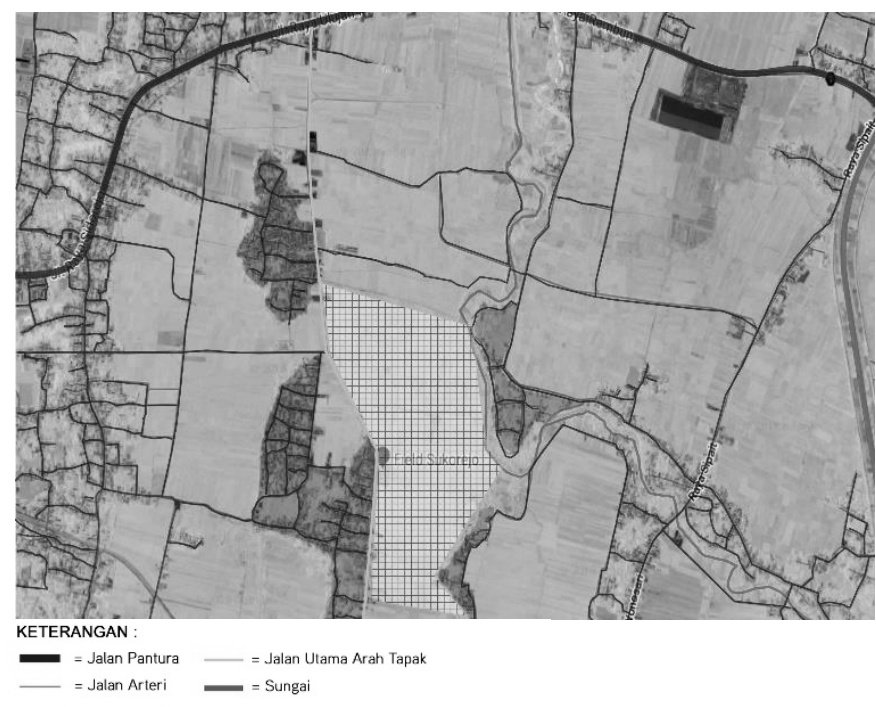

Gambar 1. Wilayah Perancangan.

METODE METAFORA
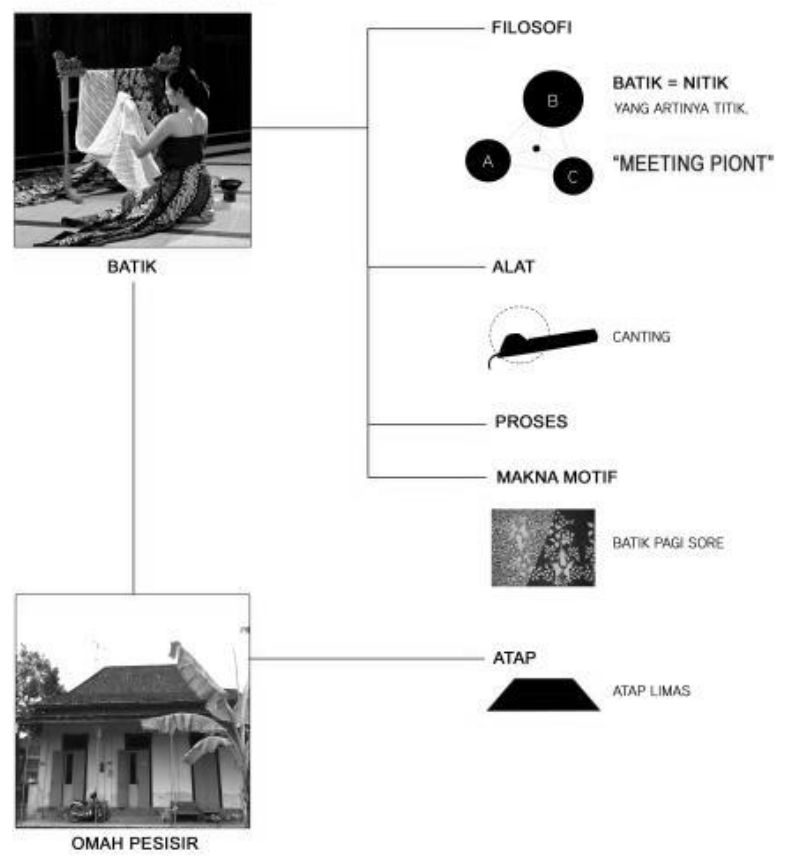

Gambar 2. Metoda metafora.

Pernyataan dan pemikiran dari sebuah gagasan di erapemerintahan Jokowi bisa diperhatikan bahwa pernyataan itu merupakan sebuah respon perkembangan aksesbilitas di Indonesia yang begitu lambat di era-sebelumnya padahal dunia semakin berkembang cepat dengan adanya globalisasi. 


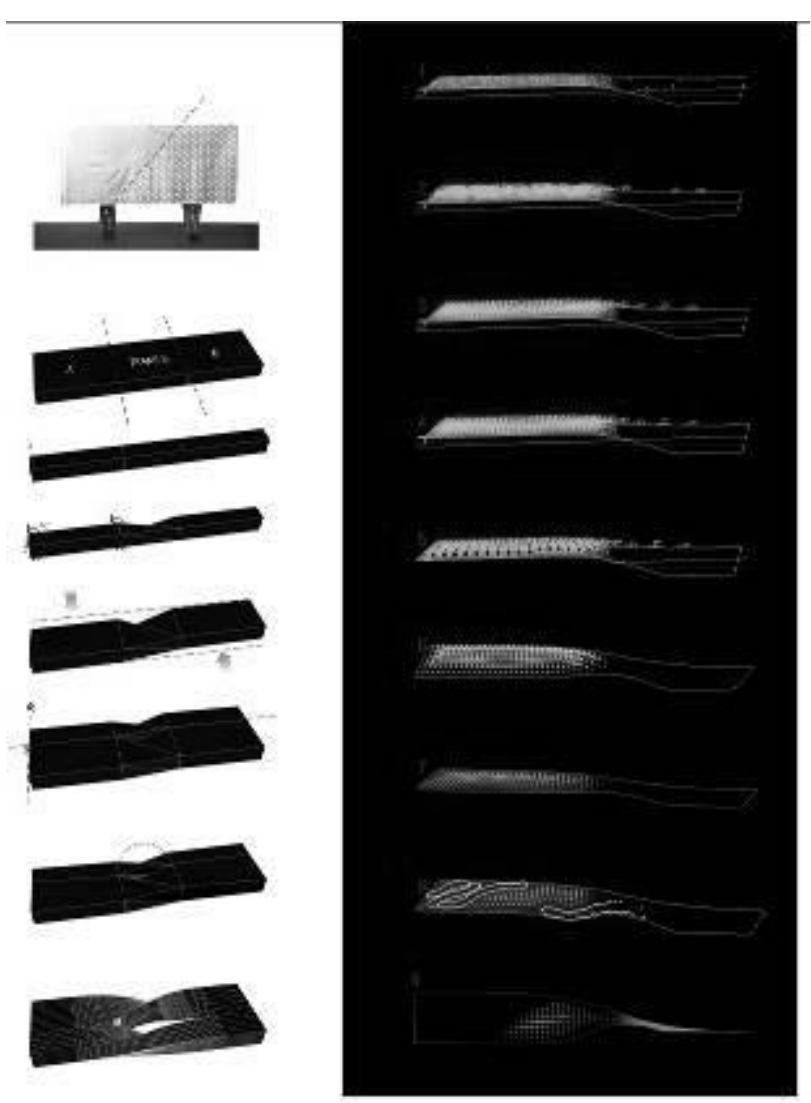

Gambar 3. Image Form: Eksplorasi Atap 1.

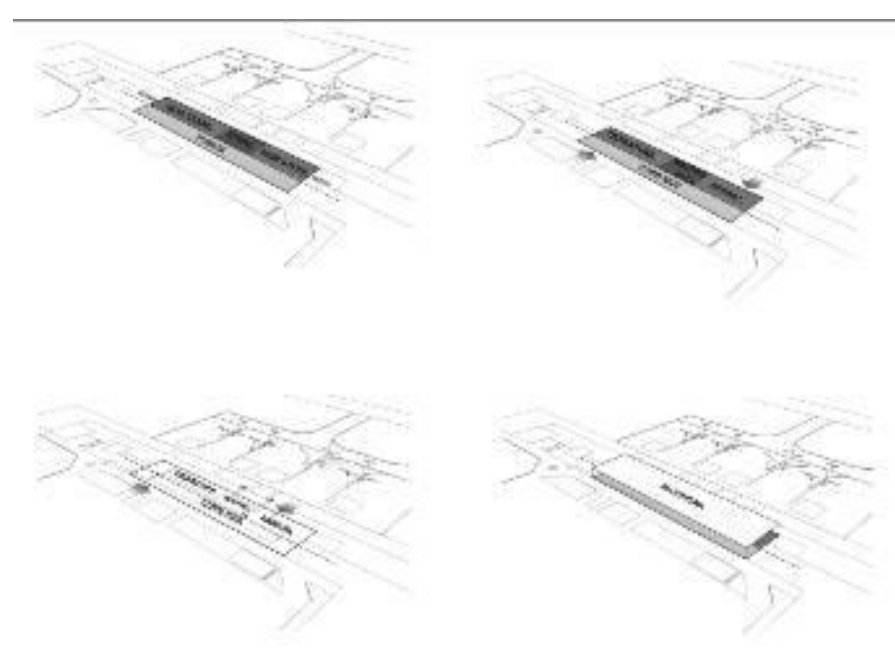

Gambar 4. Image Form: Eksplorasi Atap 2.

Selain gaya hidup yang serba cepat, budaya lokalitaspun mulai hilang. Sehingga generasi pada saat ini minim adanya pengenalan akan pemahaman budaya-budaya yang ada di Nusantara. Sangat disayangkan jika pada generasi kekinian mempunyai karakter yang tangguh dan bisa bersaing di era globalisasi tetapi pada jati dirinya tidak mempunyai identitas kelokalan.

Dalam KBBI arti identitas /iden·ti·tas/ /idéntitas/n ciri-ciri atau keadaan khusus seseorang; jati diri. Sedangkan arti regionalisme sendiri bukan suatu wujud paham dari sikap kedaerahan namun muncul sebagai akibat dari koreksi terhadap maraknya penyeragaman di seluruh dunia sehingga

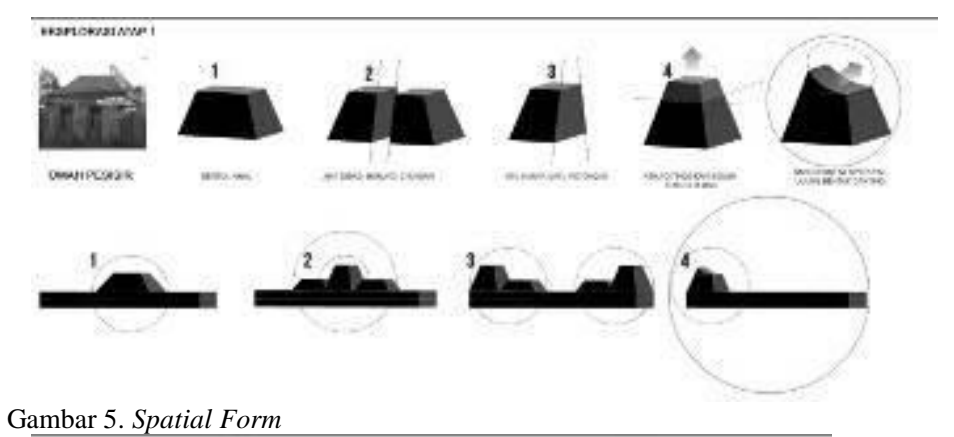

Gambar 5. Spatial Form
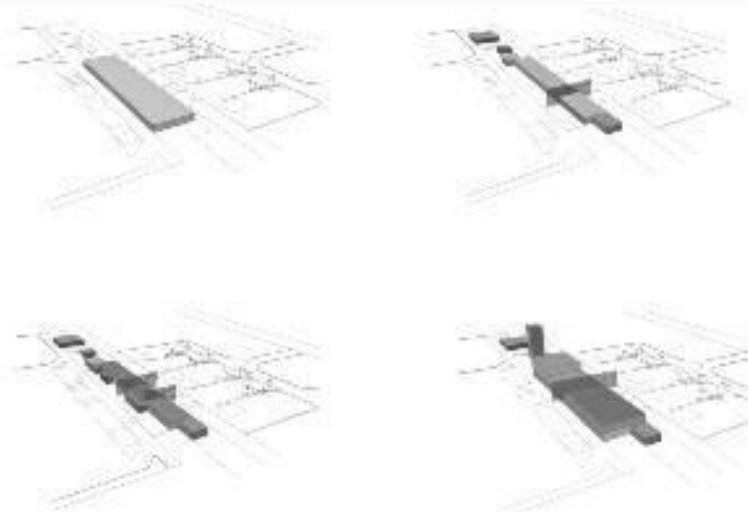

Gambar 6. Basic Form.

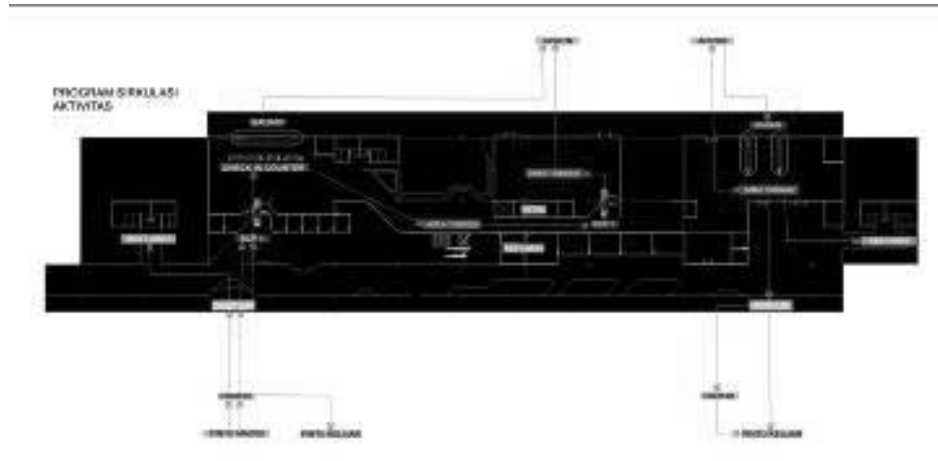

Gambar 7. Program Form

kita tidak lagi mengenal lagi mana budaya kita dan mana budaya tetangga kita. Artinya kita tidak mengenal lagi mana budaya asli daerah atau negara kita dengan daerah atau negara lain [1].

Bagaimana sebuah bangunan bandar udara yang berfungsi dengan baik, menfasilitasi orang ketika merasa bosan menunggu sekaligus kaya akan indetitas daerah?

\section{II.METODA PERANCANGAN}

Pada proses perancangan, memaknaan semiotika digunakan untuk eksplorasi informasi untuk mengungkap temuan penelitian terkait proses representasi yang berlangsung kedalam komunikasi arsitektural. Pendekatan ini juga untuk mengkaji tentang tanda indikasi, penunjukan, kemiripan, analogi, makna dan komunikasi dari bagian kehidupan masyarakatnya. Disini secara implisit, kajian semiotika terkait dengan kebiasaan atau kode sosial (social code) yang melekat di masyarakat, sehingga suatu tanda bisa dipahami maknanya secara kolektif [2]. 


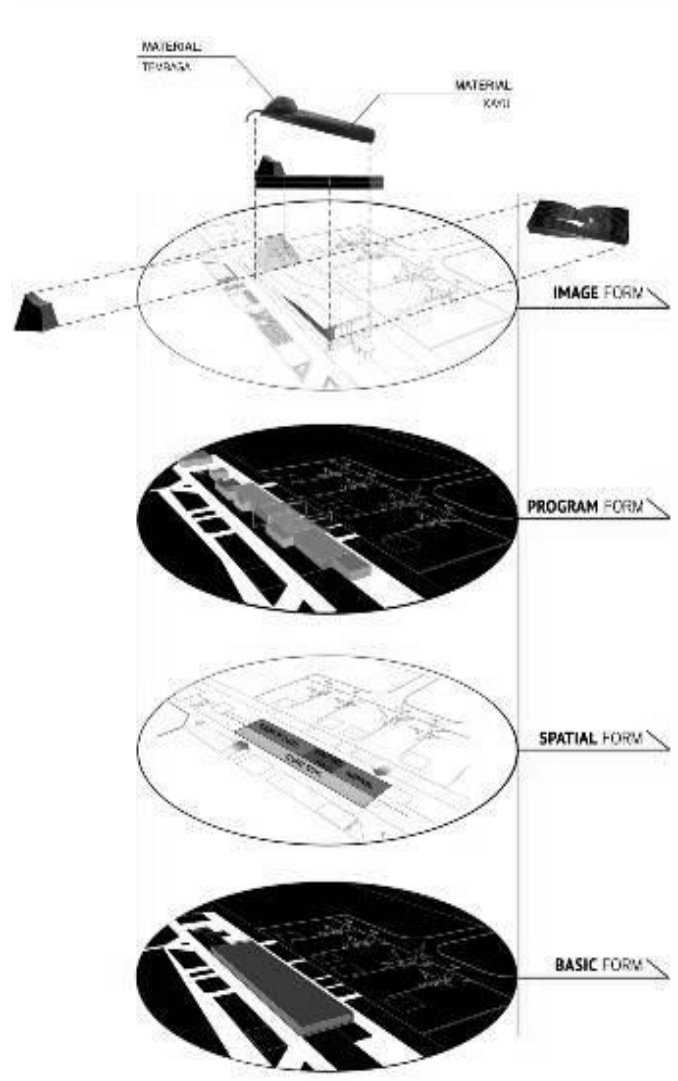

Gambar 8. Aksonometri Konsep Layering.

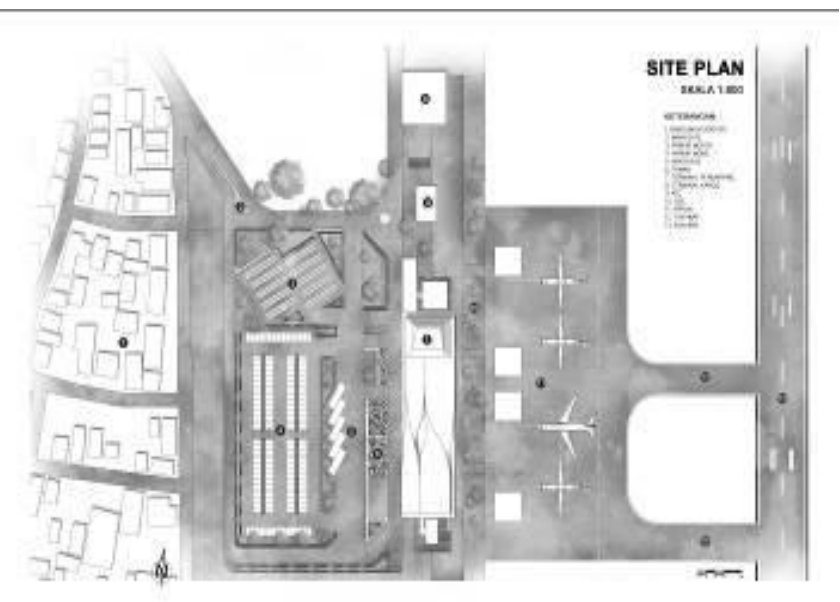

Gambar 9. Siteplan.

Hasil karya arsitektur nantinya perwujudan makna yang ingin disampaikan melalui ekspresi wujudnya. Wujud tersebut akan dimaknai kembali sebagai suatu hasil persepsi oleh pengamatnya. Perwujudan makna suatu rancangan dapat dikatakan berhasil jika makna atau 'arti' yang ingin disampaikan oleh perancang melalui rancangannya dapat dipahami dan diterima secara tepat oleh pengamatnya, jika ekspresi yang ingin disampaikan perancangnya sama dengan persepsi pengamatnya. Pendekatan semiotika dalam desain arsitektur nantinya adalah bagaimana caranya untuk mengeksplorasi kreativitas melalui penciptaan kode-kode yang

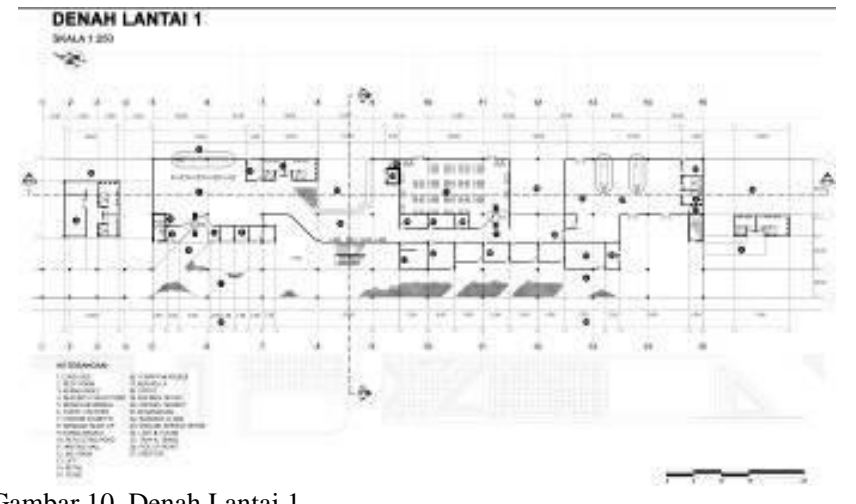

Gambar 10. Denah Lantai 1.

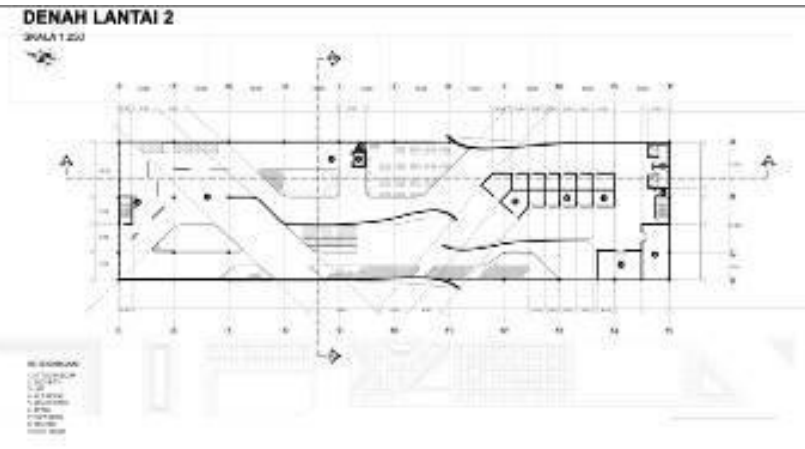

Gambar 11. Denah Lantai 2.

\section{DENAH LANTAI 3}

UNA

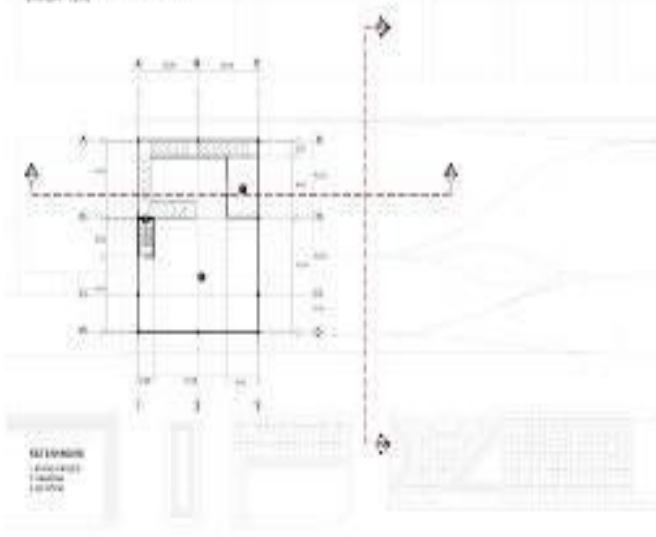

Gambar 12. Denah Lantai 3.

bisa dipahami oleh publik yang berkaitan dengan identitas daerah.

1. Metoda Metafora

Metoda ini digunakan untuk mengeksplorasi pada perancangan dengan pengandaian sesuatu yang abstrak sehingga menimbulkan banyak presepsi pada desain perancangannya. Selain itu, pemanfaatan metode ini agar pengamat mempunyai persepsi masing-masing sesuai dengan persepsi yang timbul pada saat pertama kali melihat bangunan tersebut. Combined methaphors merupakan penggabungan kategori 1 dan kategori 2 dengan membandingkan suatu objek 
visual dengan yang lain dimana mempunyai persamaan nilai konsep dengan objek visualnya.

Pada pokok identitas yang diambil dari Pekalongan adalah batik dan omah pesisir atau rumah lawang songo. Kemudian dari dua pokok identitas tersebut diterjemahkan melalui pemaknaan semiotika yang kemudian dikomunikasikan dengan metode metafora. (Gambar 2)

\section{Metoda Layering}

Metoda ini gunakan untuk mengolah komposisi layer-layer pada perancangan, layer itu sendiri berupa basic form, spatial form, methaporical or image form dan program form. Desain bandar udara sangat kompleks, sehingga komposisi perancangan sangat penting. Perlu menjadi perhatian bahwa desain sebuah bandar udara tidak cukup hanya ikonis, tetapi juga mampu memenuhi fungsi utamanya yang tidak dapat ditawar, yaitu sebagai fungsi pengatur transportasi yang memberikan keamanan, keselataman, juga kenyamanan baik kepada para pengguna maupun pekerja didalamnya.

Pemanfaatan metode layering ini adalah membantu perancangan karena tipologi bandara merupakan tipologi yang sangat kompleks dari program ruang, kebutuhannyam fungsi dan unsur kebutuhan lainnya.

Basic Form: Bentuk awal yang diciptakan pada gubahan desain dengan mengikutipola dari alam atau lingkungan pada lahan.

Program Form: Pembagian Fungsi dan organisasi ruang. Di program form ini bisa dimulai paling awal yang kemudian membentuk beberapa bentuk dasar atau bisa jadi akan menyesuaikan bentuk basic form yang telah dibentuk dari awal.

Image Form: penggunaan bentuk yang nantinya di jadikan sebagai wujud ikon atau bentuk luar dari bangunan.

Spatial Form: rancangan untuk menciptakan ruang yang memberikan pengalaman lansekap pada ruang. Sequence, Frame [3].

\section{HASIL DAN EKSPLORASI}

\section{Konsep Image Form}

Rumah Pesisir Pekalongan atau biasa disebut Omah Lawang Songo merupakan rumah asli Pekalongan yang pada sisi sebagiannya digunakan untuk berkerja, atau biasa disebut 'pranggrok' untuk membuat usaha batik. Pada karakter penghuninya biasanya seorang santri sekaligus haji. Bentuk awal atap rumah pesisir Pekalongan yang kemudian dieksplorasi bagaimana jika atapnya dibagi menjadi dua, jika hanya satu potongan saja, atau bagaimana jika atap tidak atau bagaimana jika dibagi, namun ditinggikan sesusai kebutuhan fungsi yang ada didalamnya. Kemudian dicoak menyerupai bentuk ujung canting. Begitupun juga eksplorasi posisi atapnya bagaimana jika posisinya tengah tunggal atau posisi tengah beberapa atap atau posisi diujung sisi dengan beberapa atap atau posisi yang mengikuti fungsi ruangnya. (Gambar 3)

Pada eksplorasi atap 2 diambil dari filosofi batik pagi sore. Batik sore merupakan batik yang mempunyai sisi gelap dan terang dengan pemisahan secara diagonal. Biasanya batik ini bisa dipakai ketika pagi maupun sore. Pada pembentukan awal, massa dibagi menjadi 3 bagian sesuai fungsi, keterangan
"A" merupakan zona 'little museum' dan 'B" adalah zona cafetaria. Massa dibentuk persegi agar presisi ketika diputar. Massa diputar 90' derajat menghasilkan pemisahan secara diagonal. Pada sisi bagiannya menjorok kedalam dengan fungsi sebagai penanda atau penyambutan bagian keberangkatan ataupun kedatangan. Kemudian ditambahkan satu model yang sama untuk pemisahan terhadap ruang didalamnya. Pada sisi tengah menghasilkan efek dari filosofi batik yaitu nitik, dari titik itu berfungsi sebagai titik point atau titik temu antara penumpang dan keluarganya di zona transisi. Konsep pemberian motif batik pagi sore terhadap fasad atap juga sekaligus digunakan sebagai pencahayaan. (Gambar 4)

2. Konsep Spatial Form

\section{Penzonaan Dasar}

Penzonaan dasar dengan membagi ruang berdasarkan ruang publik, semi-steril steril, sesuai dengan kaidah pada umumnya untuk pemisahan zona darat dan zona udara. Dengan pembagian seperti ini, area servis dan office disebar ketiga zona tersebut sehingga ruang-ruang dalam cernderung tersekat-sekat dan panjang.

Pemetaan Zona ke Fungsi

Pada zona publik dijadikan sebagai daerah "Curb Side" daerah paling luar ketika orang datang. Pada zona semi sterilnya dijadikan sebagai daerah kedatangan dan keberangkatan. Dan zona sterilnya dijadikan sebagai tempat menunggu, ruang paling akhir sebelum penumpang naik ke pesawat.

Pemaksimalan Sirkulasi

Sirkulasi keberangkatan dan kedatangan sekaligus hanya diletakkan pada lantai satu saja. Hal ini bertujuan sebagai pemaksimalan sirkulasi horizontal.

Anjungan Pada Lantai 2

Pada anjungan ini berfungsi sebagai "meeting point" ketika penumpang sudah mendapat boarding pass bisa bertemu kembali dengan orang tua/ kerabat. Selain itu sebagai fasilitas orang ketika bosan menunggu. (Gambar 5)

\section{Konsep Basic Form}

Massa Utama Terpusat

Konsep konfigurasi linnear, keseluruhan bandar udara hanya terdiri atas satu terminal yang terhubung sehingga mempermudah proses transit atau perpindahan pesawat. Minimize Cut \& Fill

Konsep reflecting pond, terdapat 4 reflecting pond, dua didalam ruang semi steril. Dan dua didaerah publik yang juga berfungsi sebagai rest area.

Massa Office \& Servis

Pembagian dan penataan massa operasional seperti Terminal kargo, Atc, Avsec \& ticketing, Airlines office. Konsep Massa Anjungan Pada Lantai 2 yaitu Little museum dan Cafetaria. (Gambar 6)

\section{Konsep Program Form}

Konsep sirkulasi fungsional bandar udara dimaksimalkan pada lantai satu saja. Mulai dari curb side ke security check point 1. Kemudikan check in counter hingga waiting hall dalam level yang sama. Sehingga pergerakan sirkulasinya sangat singkat dan jelas. Pada sirkulasi kedatangan juga diletakkan hanya pada lantai satu saja. (Gambar 7). 


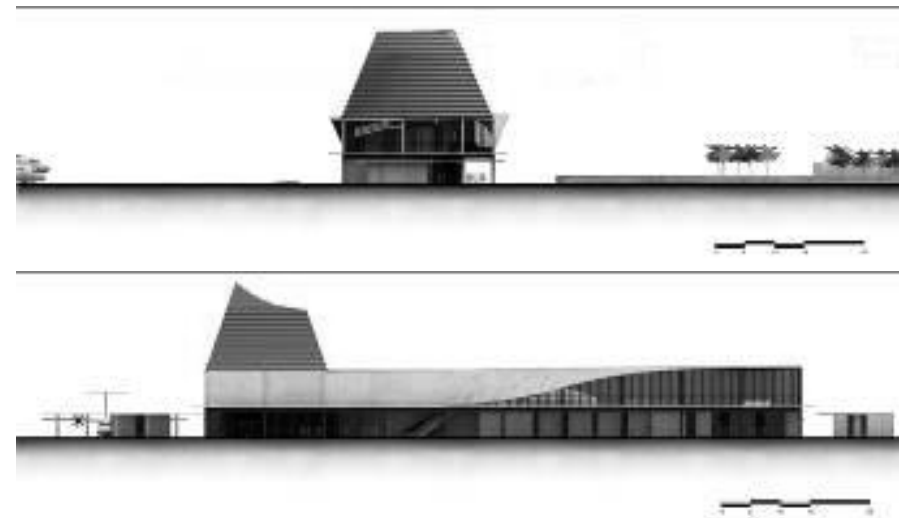

Gambar 13. Tampak.
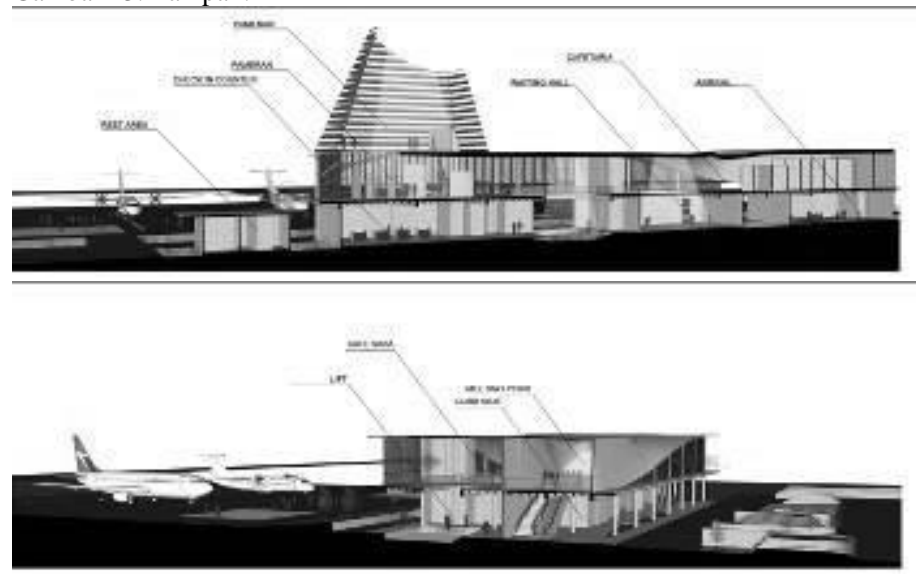

Gambar 14. Perspektif Potongan

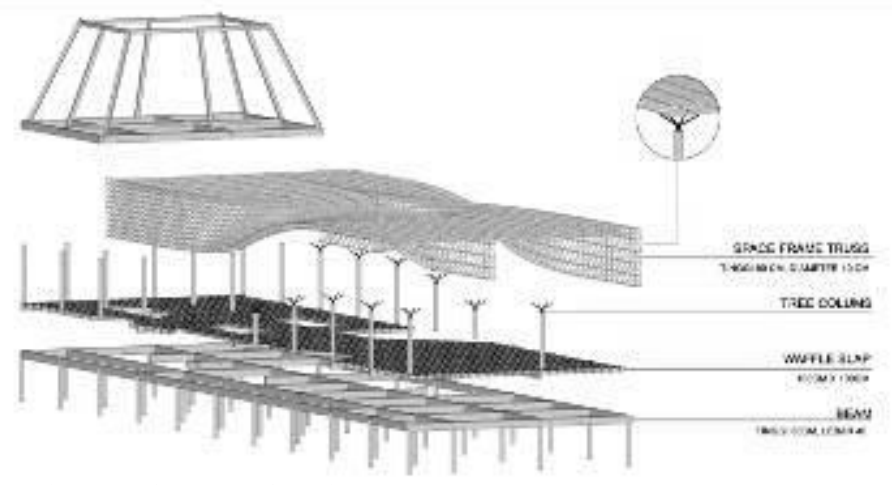

Gambar 15. Aksonometri struktur.

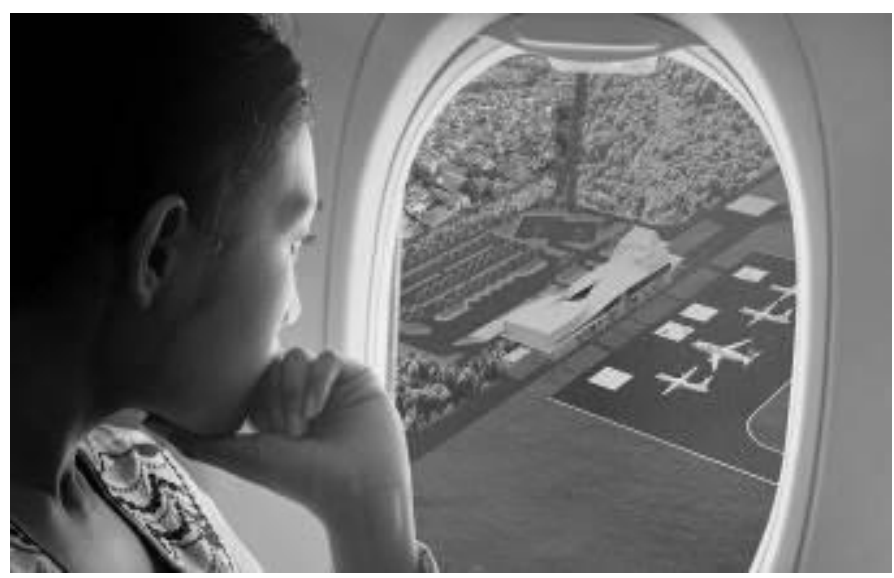

Gambar 16. Perspektif Tampak Burung.
5. Konsep Pencahayaan dan Penghawaan

Pencahayaan salah satu bagian daya tarik arsitektural dari bangunan terminal bandar udara. Pada umunya, trend lama yang lebih mengandalkan pencahayaan buatan. Terminal ini lebih mengutamakan pencahayaan alami dengan maksud penghematan energi dan mengurangi penghasilan panas dari sumber-sumber buatan. Penggunaan cahaya alami dan buatan merupakan pertimbangan khusus karena hal tersebut merupakan salah satu daya tarik arsitektural dimana terminal harus menampilkan kesan yang sama selama 24 jam. Pada siang hari pencahayaan alami merupakan pencahayaan yang dominan dalam terminal meskipun beberapa ruangan masih tetap menggunakan pencahayaan buatan, tergantung juga pada fungsi ruangan. (Gambar 14)

Untuk memaksimalkan cahaya alami pada siang hari, beberapa sisi batas ruang luas diberi kisi-kisi bukaan agar cahaya maupun udara masuk kedalam ruangan. Penghematan energi menjadi poin penting dalam desain dalam desain terminal bandar udara ini dengan memerhatikan beberapa poin antara lain;

a. Optimalisasi peletakan ventilasi sebagai penghawaan alami,

b. Optimalisasi penggunaaan pencahayaan alami,

c. Efesiensi penggunaan pendinginan ruangan.

6. Konsep Sistem Struktur

Sistem bangunannya menggunakan sistem open, seperti pada umumnya bangunan bandara dengan sistem suspended atau bentang lebar. Hal ini bertujuan agar ruang yang didalamnya lebih lega dan fleksibel. Sedangkan pada lantai 1 menggunakan sistem kolom balok. (Gambar 15)

\section{Material}

Material penutup adalah canopy yang berbahan dasar fabric dan PVC (Poly Vynil Carbonate) yang kemudian dilapisi oleh Polyester. Mudah dibentuk-bentuk, elastis. Batu alam dan kayu: Mempertahankan material nusantara dengan menggunakan material lokal. Batik Stamp: Sebagai ornamen fasad interior bangunan.

\section{KESIMPULAN}

Berdasarkan analisis melalui desain yang telah dilakukan, sejatinya bandar udara merupakan bangunan publik yang sangat kompleks. Sehingga perlunya pemahaman dan prinsip untuk memenuhi persyaratan teknis yang berkaitan dengan keselamatan dan keamanan. Hal itu dilakukan untuk menghindari terjadinya kesalahan yang fatal dalam mendesain, juga kenyamanan bagi para pengguna maupun pekerja yang ada didalamnya.

Selain fungsi yang maksimal, fasilitas-fasilitas penunjang yang juga berfungsi sebagai ruang edukasi diharapkan mampu membantu permasalahan yang biasanya sering terjadi, yaitu ketika bosan menunggu. Adanya little museum dimaksudkan pengguna dapat mengetahui segala informasi dan sejarah yang ada di Pekalongan.

Pada akhirnya, bandar udara merupakan sebuah pintu gerbang suatu daerah sekaligus simbol suatu kota. Desain ini merupakan sebuah pengoreksian atas pembangunan bandar 


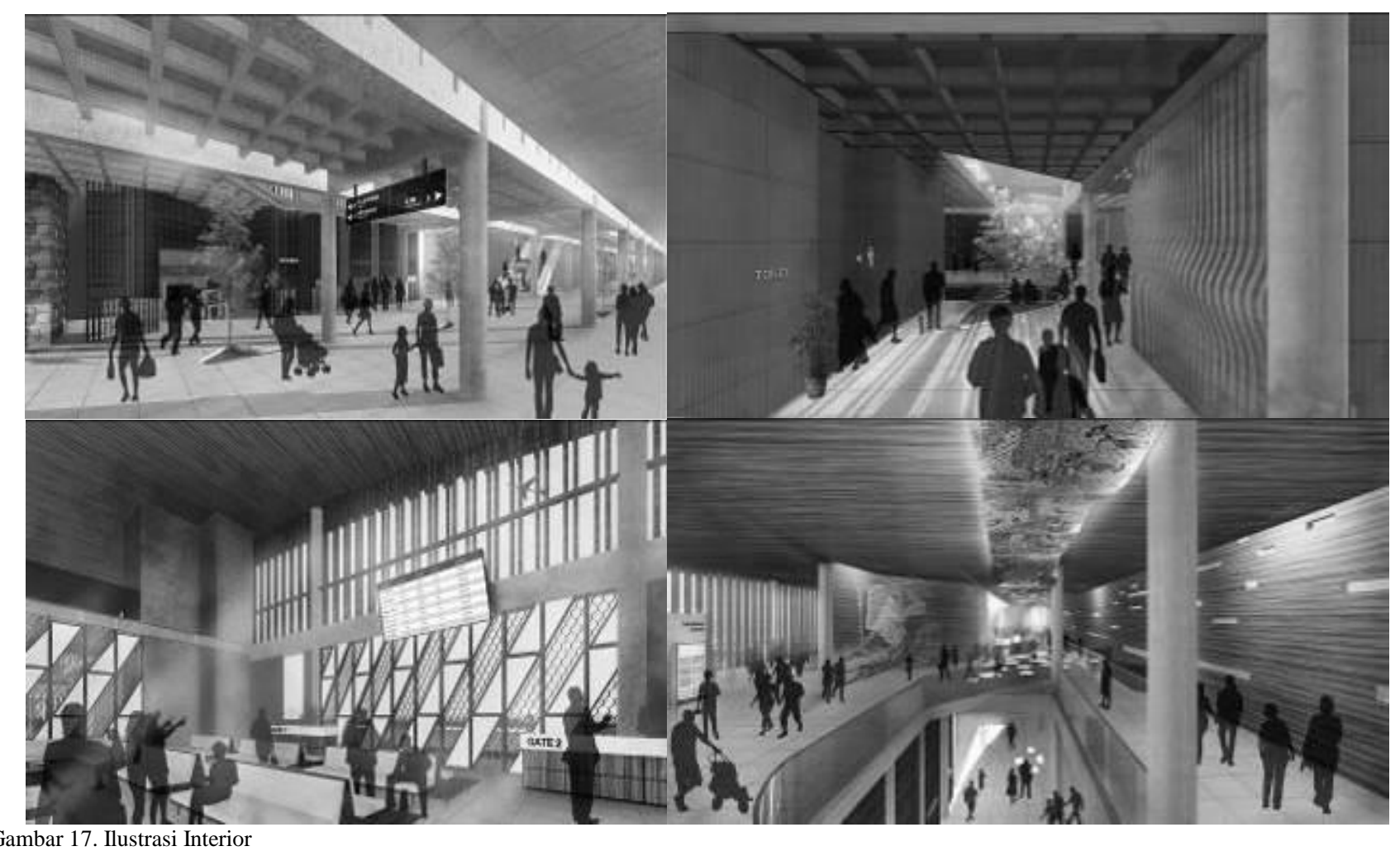

Gambar 17. Ilustrasi Interior

udara di Indonesia yang saat ini lebih kearah internasional dengan segala konsep teknologi yang terkadang melupakan identitas lokalitasnya, sehingga tidak bisa membedakan mana budaya kita mana budaya tetangga kita.

\section{DAFTAR PUSTAKA}

[1] C. Abel, Architecture and Identity. New York: Routhledge, 1997.

[2] C. Sanders Peirce, Peirce on Signs: Writings on Semiotic. Chapel Hill and London: The University of Nort Carolina Press, 1991.

[3] D. Jauslin, Architecture with Landscape Methods Case Study of the Rolex Learning. 2010. 